\title{
ANALYSIS OF FACTORS THAT AFFECT TO INFRASTRUCTURE IMPROVEMENT OF SYUKURAN AMINUDDIN AMIR AIRPORT IN BANGGAI DISTRICT
}

\author{
Sutrisno Mustaman ${ }^{1}$, Fahira $\mathbf{F}^{1}$, dan Nirmalawati' ${ }^{1}$ \\ 1) Department of Civil Engineering, Faculty of Engineering, Tadulako University, Palu \\ ainunafira@gmail.com
}

\begin{abstract}
The airport is one of the important infrastructures in the air transportation field that functions to provide aircraft flight services so that there is a need for compatibility between the fleet and its infrastructure, in this case improving the infrastructure of Syukuranan Aminuddin Amir (SAA) Airport. The aim of this study is to analyze the factors that influence the improvement of the infrastructure of SAA Airport. The location of the study was conducted at the SAA Airport, Banggai Regency, Central Sulawesi Province. Data collection was carried out by distributing questionnaires to 120 respondent passengers on airplanes who use the SAA airport. Data analysis using factor analysis methods. The analysis result shows there are 11 factors that affect infrastructure improvement of SAA Airport is socio-economic, airport service quality, operator service quality, flight traffic demand, air transport service demand, air transportation mode selection, airport departure facility (waiting room) and airplane ticket purchase decisions, parking area and waiting room, flight schedule and potential regional commodity yields, service and process baggage handling, and transportation accessibility to the airport.
\end{abstract}

Keywords: airport; factor analysis, improvement, infrastructure 


\section{INTRODUCTION}

\subsection{Background}

In order to improve the performance of air transportation infrastructure, it is necessary to describe the condition of air transportation infrastructure based on air traffic and the viewpoints of various stakeholders such as the central government, regional governments, academics, and practitioners (Rarasati, Mohammad, \& Latief, 2016). If it is assessed from the point of view of the central and regional governments the increase in passenger growth is the main indicator of air transportation performance while the growth of goods is only a secondary indicator. For planning the improvement and development of airport infrastructure must estimate traffic flows in the future (Taula, Jansen, \& Rumayar, 2017).

The airport is one part of the infrastructure that has an important role in improving the quality of life and human welfare. The airport is also an entry point for foreign and domestic investors and tourists who will drive the economy area. Banggai Regency, Central Sulawesi Province has an airport that still requires an increase in a variety of adequate transportation facilities so that public services can be optimal and can open access to small areas that exist. SAA Airport is a small airport with only one runway and one terminal. The airport is located only 20 meters from the sea, about $10 \mathrm{~km}$ south of Luwuk city center. It has a runway, taxiway, apron, Turning Area, OverRun, Shoulder, and strip facilities. when in good condition (Anonim, 2018). The current condition of airports based on the movements of aircraft arriving and departing from 2011 to 2017 is relatively stable.

\subsection{Research purposes}

The purpose of this research is to find out the factors that influence the improvement of SAA Airport infrastructure by using factor analysis as well as to classify and name sub-factors that influence the improvement of SAA Airport infrastructure

\subsection{Benefits of Research}

This research is expected to provide input for practitioners or related parties to be able to know and consider the factors that influence the improvement of airport infrastructure, as well as consider factors that affect the movement of aircraft and passenger activities in improving airport infrastructure. 


\section{LITERATURE REVIEW}

\subsection{Benefits of Air Transportation}

Transportation is defined as the activity of transporting or moving cargo (people or goods) from one place to another, or from a place of origin to a destination, or Origin-Destination Travel. Based on this understanding, air transportation can be given a definition, namely as an activity that transports or moves passengers and cargo from an original airport to the destination airport, by plane. Aircraft as a mode of air transportation has characteristics, which have high speed and are able to reach places that cannot be served by other modes of transportation (land transportation and sea transportation). Air transportation has an advantage in high speed compared to other transportation, providing a very large under construction.

\subsection{Airport Infrastructure}

Airport development is a job that requires the availability of large amounts of capital and is complex. Capital intensive because airport development requires substantial construction and installation investment. On the other hand, airport development is a complex activity because it requires the integration of various occupations and areas of expertise, including intra-mode and intermodal transport integration within the coverage area served. Therefore, the development and development of an airport requires careful planning so that investments can be made efficient (efficient) and effective (effective) (Adisasmita, 2012).

Airport management is very important and plays a role in increasing economic growth because every time there is the movement of aircraft traffic that comes and goes to or from an airport both from within and outside the country. Airport management needs intense planning and communication to the public, workers, airline industry companies, and political power. The private sector needs to be involved in the form of cooperation operations and management contracts with major capital expenditure, which is most realized in the cooperation of the government and the private sector in airport management (Setiani, 2015).

\subsection{Factors That Influence Airport Infrastructure Improvement.}

Infrastructure development and improvement is the development of the performance of infrastructure facilities and infrastructure. To improve the overall performance of the airport, airport service levels, or characteristics of the airport's facilities are required. Like the number and growth of passengers, the number and 
growth of cargo (goods), and policies implemented by the government regarding air transportation infrastructure (Rarasati et al., 2016). Airport upgrading has an influence or impact on various aspects, one of which is land use. The bigger and more passengers who travel at an airport, the greater the consequences of changes in land use around it. This can be seen from the emergence or growth of supporting activities that will complement the main activities at the airport (Kusumawati, Nurhadi, \& Rini, 2017). There are several factors that affect airport infrastructure that needs to be improved or developed, among others: location (land) factors, spatial and regional planning factors, relatively flat topographical factors, population, suitability to land use, socio-economic impacts of the population, environmental impact, technical aspects, indications of the airport's own financial or investment needs, gross domestic product factors, revenue capability factors, traffic demand factors (Anwar, 2015; Cui \& Kuang, 2013). Traffic demand factors include demographic, socio-economic, political, geographic, external factors and actions taken by airports (Anwar, 2015). Some other indicators that also affect traffic, namely ethnicity, airplane tickets, the quality of service on the plane, access, as well as tariffs, and service quality. Economic factors in question are gross domestic income and money exchange rates. Gross domestic income is related to how the level of community income, while the exchange rate will affect the number of trips. Demographic factors such as population or population of an area and the occurrence of urbanization. The supply factor is an indicator of aviation service providers. The supply, factors included transportation costs (passengers per $\mathrm{km}$ ), aircraft size, fuel costs, technology (navigation, communication, etc.), management (flight network, new routes, etc.), capacity limitations, and price of airline tickets. Economic regulatory factors, such as airline and airport privatization, free trade, open skies, foreign ownership and tax regulations. Environmental regulatory factors, for example, are the imposition of a carbon tax which has an additional impact on travel costs. The factor of cargo transportation, which is related to the needs of air logistics transportation.

\section{RESEARCH METHOD}

\subsection{Types of research}

This type of research is a quantitative descriptive research method that is descriptive and uses more analysis. Quantitative research aims to find 
relationships that explain causes in measurable social facts, show the relationship of variables, and analyze the relationship of these variables.

\subsection{Location of study}

The location of the study was SAA Airport, Banggai Regency, Central Sulawesi Province. Covers the stages of preparation, data collection, data analysis, and preparation of research results.

\subsection{Population and Sample}

The population used in this study are the elements of the stakeholders associated with the preparation of strategy and policy capacity of SAA Airport and aircraft passengers. The questions arranged refer to the research variables with a sample size of 120 respondents. A large number of samples in the factor analysis method depends on the number of indicators used in the study, which is multiplied 5-10 times (Ferdinand, 2012), wherein this study 12 indicators are used so that the number of samples needed is $12 \times 10=$ 120 respondents

\subsection{Operationalization of Variables}

The research variable is basically anything in the form of whatever has been determined by the researcher to be studied so that the information obtained is then drawn from the conclusion (Sugiyono,
2009). The variables used in this study are socioeconomic variables, traffic demand, and airport technical variables. The variables in this study are formulated as factors or constructs, i.e. variables formed through observed dimensions or observed indicators

\subsection{Research Instruments}

The parameters studied in this paper are the factors that influence the improvement of the infrastructure of SAA Airport. The measurement scale that will be used in this study is to use a Likert scale, which is a scale used to measure the attitudes, opinions, and perceptions of a person or group of people about social phenomena (Sugiyono, 2009). With a Likert scale, the variables to be measured are translated into indicator variables. The indicator then becomes the starting point for compiling instrument items which can be statements and questions.

The instrument used in this study was a questionnaire. The questionnaire used refers to a predetermined, modified operational definition (form and number) then the questions are adjusted based on phenomena that have to do with the improvement of the infrastructure of SAA Airport related to the perceptions and expectations of airport stakeholders and passengers who use airlines. 
The validity of a research result is determined by the measuring instrument used because a valid measurement tool describes the state of the research object which is actually. For this reason, two types of testing are needed, namely the validity test (validity test) and the reliability test (reliability test).

\subsection{Data analysis technique}

The data analysis technique used is the quantitative descriptive analysis method and the statistical analysis method. The quantitative descriptive analysis method is applied to data obtained from direct interviews. While the statistical analysis method aims to determine the factors that influence the improvement of the infrastructure of SAA Airport, this method is applied to the data obtained from the results of questionnaires by respondents. Then the data were examined by the factor analysis method with the help of SPSS version 17 (Rahmiyanti, 2019).

\subsubsection{Keizer Meyer Olkin (KMO)}

$\mathrm{KMO}$ test is conducted to determine whether the factors in this study are valid or not. The number of KMO and Barlette tests must be above 0.5 . This provision is based on criteria, if the probability is significant $<0.05$, the research variables can be predicted and analyzed further but if the probability is significant $>0.05$ then the research variables cannot be analyzed further (Rahmiyanti, 2019).

\subsubsection{The Measure of Sampling Adequacy (MSA) \\ MSA is another measure used to} measure the interrelationships between variables and the suitability of factor analysis. The value shown is MSA $\geq 0.5$. However, if the variable with an MSA value $<0.5$, then the analysis process must be done again in the same way, but must first discard variables that do not meet the requirements. At the stage of the factor analysis process, after selecting the appropriate variables to analyze the factors by conducting KMO and Bartlett's Test, MSA Test, then determining the number of factors by extracting variables and factor rotations, and finally mentioning these factors (Rahmiyanti, 2019).

\section{RESULTS AND DISCUSSION \\ 4.1 Validity test}

A validity test is used to determine the extent of the accuracy and accuracy of a measuring instrument in carrying out its measurement function. The validity test in this study used item analysis that correlates the score of each item with the total score which is the sum of each item score. If an item does not meet the requirements, then the item will not be further investigated. 
Test the validity of a measuring instrument shown from its ability to measure the questionnaire given to respondents. If all the instruments of the questionnaire tested are appropriate, then the instrument is said to be valid. The criterion for evaluating the validity test is if $r$ count $>r$ table, then the instruments of the questionnaire are valid. Based on the results of the validity test carried out using the SPSS version 17 program on 65 items, the results showed that there were 22 items that were declared insignificant because the $\mathrm{p}$-value $>0.05$. So that only 43 items in this research instrument were significant and could be further investigated.

\subsection{Reliability Test}

Reliability is a level that measures the consistency of results if repeated measurements are made on a characteristic (Malhotra, Nunan, \& Birks, 2007). The answer scores for each item were tested for reliability with the aim of showing the extent to which the measurements gave relatively no different results if the measurements were taken again on the same subject regarding stability, reliability/stability, and circumstances did not change in the first observation period. Reliability test for 43 items in order to find out the consistency of a series of measurements. By using the Cronbach
Alpha formula, the Cronbach Alpha coefficient value $>0.7$ for 43 items, because the reliability test results are valued at $r$ close to 1 , this data shows high reliability to used as a research instrument.

Table 1. Value of Reliability Statistics

\begin{tabular}{cc}
\hline Cronbach's Alpha & N of Items \\
\hline 0.918 & 65 \\
\hline
\end{tabular}

Based on Table 1, the Alpha Cronbach's coefficient is 0.918 which indicates the value is greater than 0.70 , so it can be concluded that the measurement results of existing variables are reliable to be used in the next analysis, namely Factor Analysis.

\subsection{Descriptive Analysis}

Quantitative descriptive analysis aims to determine the highest average score of respondents answers. The number of factors analyzed was 3 factors and 12 indicators and the total sub-indicators were 65 items. By using a Likert scale, it can be seen that the highest choice of respondents' answers is (X1) "airport has adequate, orderly and safe parking area" (4.4), (X4) "airport officials are easily recognized and easily questioned" (4.7), (X10) "airconditioned waiting rooms are quite comfortable (clean)" (4.6), and (X54) "passenger airplane ticket processing is fast" (4.4). 


\subsection{Statistic analysis}

The factor analysis determines by using SPPS version 17. The first analysis was carried out with the KMO test and the Bartlett test on 45 significant items. The KMO test and the Bartlett test are used to determine the feasibility of a variable whether it can be further processed using factor analysis or not (Table 2).

Table 2. KMO and Bartlett's Test

\begin{tabular}{llr}
\hline Kaiser-Meyer-Olkin & \\
Measure of Sampling & \\
Adequacy. & & 0.777 \\
\hline Bartlett's & Approx. & \\
Test & of \\
Sphericity & Chi-Square & 3218.584 \\
\cline { 2 - 3 } & Df & 903 \\
\cline { 2 - 3 } & Sig. & 0.000 \\
\hline
\end{tabular}

From this result because the KMO value $>0.5$ and significant Bartlet $<0.05$ this means that the variables can be predicted and analyzed further. The following analysis is testing the adequacy of the sample through the KMO measure of Sampling Adequacy Index (SAI) and the value of Bartlett's Test of Sphericity (BTS). This index is used to examine the accuracy of the use of factor analysis. If the KMO value is between 0.5 to 1 and the significance of BTS is less than the significance level () used, it can be interpreted that the factor analysis is appropriate. The KMO value is 0.777 and the significance value of BTS is 0.000 this indicates that the proper factor analysis is used to simplify the collection of 43 variables. This shows that data can be carried out for the next factor analysis stage. In determining the number of factors that need to be seen, the initial eigenvalue is total $>1$ and is expected to give a cumulative percentage of variance $>60 \%$. In this study, there are 43 independent variables studied which then produce 11 factors and form the cumulative variance percentage of $72.330 \%>60 \%$.

By extracting the initial variables into 11 factors, cumulative variance yields a percentage of $71.071 \%$, this shows that of the 11 factors formed, it can represent 43 variables that affect the improvement of airport infrastructure. Where factor extraction is the process of reducing the number of variables into a number of new variable sets or fewer factors. Using the PCA (Principal Component Analysis) method, the Component Matrix values of 11 components have been obtained, then the values of the rotated matrix components can be seen in Table 3. To determine the variables that enter into a factor, then select the loading factor. greater value and each variable must have a loading factor value $>0.40$. 
Table 3. Total Variance Explained

\begin{tabular}{cccccccccc}
\hline \multirow{2}{*}{ Component } & \multicolumn{3}{c}{ Initial Eigenvalues } & \multicolumn{3}{c}{ Loadings } & \multicolumn{3}{c}{ Loadings } \\
\cline { 2 - 10 } & Total & $\begin{array}{c}\% \text { of } \\
\text { Variance }\end{array}$ & $\begin{array}{c}\text { Cumulative } \\
(\%)\end{array}$ & Total & $\begin{array}{c}\% \text { of } \\
\text { Variance }\end{array}$ & $\begin{array}{c}\text { Cumulative } \\
(\%)\end{array}$ & Total & $\begin{array}{c}\% \text { of } \\
\text { Variance }\end{array}$ & $\begin{array}{c}\text { Cumulative } \\
(\%)\end{array}$ \\
\hline 1 & 12.959 & 30.137 & 30.137 & 12.959 & 30.137 & 30.137 & 4.748 & 11.042 & 11.042 \\
2 & 3.088 & 7.181 & 37.139 & 3.088 & 7.181 & 37.139 & 4.291 & 9,979 & 21.021 \\
3 & 2.620 & 6.093 & 43.412 & 2.620 & 6.093 & 43.412 & 3.570 & 8.303 & 29.324 \\
4 & 2.087 & 4.852 & 48.264 & 2.087 & 4.852 & 48.264 & 3.484 & 8.103 & 37.427 \\
5 & 1.808 & 4.205 & 52.469 & 1.808 & 4.205 & 52.469 & 2.527 & 5.876 & 43.303 \\
6 & 1.737 & 4.040 & 56.509 & 1.737 & 4.040 & 56.509 & 2.266 & 5.271 & 48.574 \\
7 & 1.633 & 3.798 & 60.307 & 1.633 & 3.798 & 60.307 & 2.127 & 4.947 & 53.522 \\
8 & 1.296 & 3.013 & 63.320 & 1.296 & 3.013 & 63.320 & 2.010 & 4.674 & 58.195 \\
9 & 1.226 & 2.851 & 66.172 & 1.226 & 2.851 & 66.172 & 1.997 & 4.644 & 62.840 \\
10 & 1.077 & 2.505 & 68.676 & 1.077 & 2.505 & 68.676 & 1.908 & 4.436 & 67.276 \\
11 & 1.030 & 2.395 & 71.071 & 1.030 & 2.395 & 71.071 & 1.632 & 3.795 & 71.071 \\
\hline
\end{tabular}

Table 3 shows that all variables have a loading factor value $>0.4$, which means that all variables analyzed have a significant effect on improving airport infrastructure. The naming of factors by researchers is:

1. Factor 1: socio-economic, which consists of 8 sub-factors.

2. Factor 2: airport service quality, which consists of 6 sub-factors.

3. Factor 3: service operator quality, which consists of 7 subfactors.

4. Factor 4: flight traffic demand, which consists of 5 sub-factors.

5. Factor 5: air transport service demand, which consists of 4 sub-factors.
6. Factor 6: air transportation mode selection, which consists of 3 sub-factors.

7. Factor 7: airport departure facilities (waiting rooms) and flight ticket purchase decisions, which consists of 3 sub-factors.

8. Factor 8: the parking area and the comfort of the airport waiting room, which consists of 3 sub-factors.

9. Factor 9: flight schedules and potential yields of regional commodities, which consists of 2 sub-factors.

10. Factor 10: service officers and processes airport baggage handling, which consists of 2 sub-factors. 
11. Factor 11: accessibility of transportation to the airport, which consists of 1 subfactor.

\section{CONCLUSIONS}

Based on the results of the discussion, it can be concluded that there are 11 factors consisting of 43 sub-factors that influence the improvement of the infrastructure of SAA Airport is socioeconomic, airport service quality, operator service quality, flight traffic demand, air transport service demand, air transportation mode selection, airport departure facility (waiting room) and airplane ticket purchase decisions, parking area and waiting room, flight schedule and potential regional commodity yields, service and process baggage handling, and transportation accessibility to the airport.

Notes. This paper was presented in $2^{\text {nd }}$ WUICACE (Warmadewa University International Conference On Architecture and Civil Engineering), 17 October 2019 at Warmadewa-University, Denpasar Bali

\section{REFERENCES}

Adisasmita, S. A. (2012). Penerbangan dan Bandar Udara. Yogyakarta: Graha Ilmu.

Anonim. (2018). Data validation and airport facilities. Luwuk.

Anwar, F. (2015). Kajian Kausalitas Permintaan Trafik Terhadap Kapasitas Bandara Berdasarkan Persepsi Pengelola Bandara (Studi
Kasus: Bandara Internasional Soekarno-Hatta). WARTA ARDHIA, 41(1), 11-18.

Cui, Q., \& Kuang, H. (2013). Important influencing factors analysis of airport sustainable development capacity: the case of China. Journal of Airline and Airport Management, 3(1), 3147.

Ferdinand, A. (2012). Metode Penelitian Manajemen. Semarang: Badan Penerbit Universitas Diponegoro.

Kusumawati, S., Nurhadi, K., \& Rini, E. F. (2017). Pengaruh perkembangan Bandara Internasional Adi Soemarmo terhadap perubahan penggunaan lahan di sekitarnya. Region: Jurnal Pembangunan Wilayah Dan Perencanaan Partisipatif, $\quad 7(2), \quad 82-95$. https://doi.org/10.20961/region.v7i2. 11578

Malhotra, N. K., Nunan, D., \& Birks, D. F. (2007). Marketing Research: an applied approach (3rd Europe). Harlow, UK.: Pearson Education.

Rahmiyanti, Z. A. (2019). Analisis faktor yang mempengaruhi keputusan konsumen dalam pembelian perumahan pasca gempa di Kabupaten Sigi. Universitas Tadulako.

Rarasati, A. D., Mohammad, I. H., \& Latief, Y. (2016). Evaluasi Kinerja Infrastruktur Transportasi Udara di Ibukota Provinsi. WARTA ARDHIA, 42(4), 185-194.

Setiani, B. (2015). Prinsip-Prinsip Manajemen Pengelolaan Bandar Udara. Jurnal Ilmiah WIDYA, 3(1), 25-32.

Sugiyono. (2009). Metode Penelitian Kuantitatif Kualitatif dan $R \& D$. Bandung: Alfabeta. 
Taula, A. D., Jansen, F., \& Rumayar, A. L. E. (2017). Perencanaan Pengembangan Bandar Udara Kasiguncu Kabupaten Poso Provinsi Sulawesi Tengah. JURNAL SIPIL STATIK, 5(5). 